\title{
PENGARUH KOMPENSASI EKSEKUTIF DAN KEBERAGAMAN GENDER DIREKSI TERHADAP KECURANGAN LAPORAN KEUANGAN
}

\author{
Susmita Dian Indiraswari \\ Fakultas Ekonomi dan Bisnis, Universitas PGRI Kanjuruhan Malang \\ Email : susmitadian@gmail.com
}

\begin{abstract}
ABSTRAK
Penelitian bertujuan untuk menguji secara empiris pengaruh kompensasi eksekutif dan pengaruh keberagaman gender direksi terhadap kecurangan laporan keuangan. Populasi penelitian ini diperoleh dari perusahaan publik sektor manufaktur yang terdapat di Bursa Efek Indonesia. Data diperoleh dari website perusahaan dan website Bursa Efek Indonesia. Teknik analisis menggunakan metode regresi berganda. Terdapat 397 observasi yang diperoleh selama tahun 2016-2018 dengan menggunakan teknik purposive sampling. Hasil penelitian menunjukkan bahwa kecurangan laporan keuangan dapat diturunkan melaui keberagaman gender direksi. Penelitian ini memberikan bukti empiris terhadap Gender Socialization Theory. Penelitian ini bermanfaat untuk pemegang saham yakni pemegang saham tidak perlu memperhatikan kompensasi eksekutif tetapi para pemegang saham perlu memperhatikan adanya keberagaman gender direksi pada suatu perusahaan.
\end{abstract}

Kata Kunci: Kompensasi Eksekutif, keberagaman Gender Direksi, Kecurangan Laporan Keuangan

\section{PENDAHULUAN}

Kecurangan laporan keuangan dalam dunia bisnis saat ini bukan hal yang asing lagi. Kasus kecurangan laporan keuangan telah menimbulkan kerugian yang sangat besar terhadap banyak pihak. Kerugian yang dapat ditimbulkan dapat berupa penurunan harga saham perusahaan (Mammen \& Edakalathur, 2019) dan penurunan kinerja perusahaan (Finnerty, Hegde, \& Malone, 2016) serta dampak-dampak buruk lainnya yang dapat merugikan perusahaan.

Kasus-kasus kecurangan laporan keuangan tidak hanya terjadi di dunia internasional saja, di Indonesia sendiri juga telah banyak terjadi kasus-kasus kecurangan akuntansi, yaitu seperti kasus yang menjerat PT Bank Bukopin Tbk. Perusahaan ini memalsukan angka laba dengan memalsukan pendapatan dari kartu kredit dan total pendapatan bunga pada laporan keuangan periode 2016. Laba yang dilaporkan dalam laporan keuangan pada periode 2016 yaitu sebesar Rp1,08 triliun yang kemudian pada tahun 2017 laba tahun 2016 tersebut direvisi menjadi sebesar Rp183,53 miliar.

Kecurangan laporan keuangan pada perusahaan manufaktur juga pernah terjadi di tahun 2001 yakni pada perusahaan Kimia Farma (Syahrul, 2003). Manajemen merekayasa laporan keuangan dan menimbulkan kesesatan publik. Pihak Kimia Farma melakukan kecurangan pada laba bersih laporan keuangan tahun 2001, yaitu sebesar Rp132 miliar dari yang seharusnya hanya Rp99 miliar. Mark-up dilakukan pada pos persediaan dan penjualan. Kantor Akuntan Publik Hans Tuanakotta \& Mustofa (HTM) terlibat dalam kasus tersebut. Masing-masing dari manajemen maupun KAP mendapatkan sanksi dan denda sesuai Pasal 5 huruf N Undang-Undang No.8 Tahun 1995 tentang Pasar Modal.

Kecurangan laporan keuangan pada dasarnya terjadi ketika pendapatan dimanipulasi secara sengaja dengan tujuan untuk menyesatkan para pemangku kepentingan lain yang dapat diikuti dengan penuntutan pidana (Hoi \& Robin, 2010). Kecurangan laporan keuangan merupakan bentuk ekstrim dari manajemen laba, dikarenakan tindakan manajemen laba dilakukan dengan cara ilegal. Banyak faktor yang dapat mendorong seseorang untuk melalakukan tindakan kecurangan laporan keuangan salah satunya yaitu kompensasi eksekutif (Conyon \& He, 2014). Eksekutif dalam perusahaan memegang peranan strategis dan merupakan pihak-pihak yang mengambil keputusan di dalam perusahaan (Hanafi \& Harto, 2014), yakni mereka menjabat pada posisi top management seperti jajaran direksi dan komisaris perusahaan. Oleh karena itu, tingkat kecurangan yang dilakukan oleh eksekutif perusahaan cenderung menjadi lebih tinggi. Eksekutif perusahaan memiliki kesempatan lebih besar untuk melakukan kecurangan dibandingkan pihak lain di dalam perusahaan, karena fungsi pengambilan keputusan strategis yang dimilikinya.Kompensasi kepada eksekutif merupakan suatu bentuk penghargaan yang dapat berupa material ataupun non-material yang diberikan kepada manajemen perusahaan agar termotivasi untuk mencapai tujuan perusahaan dengan baik (Dewi \& Sari, 2015). 
Mekanisme pemberian kompensasi yang tepat kepada eksekutif perusahaan dapat mengurangi kecenderungan eksekutif dalam melakukan tindakan kecurangan. Hal ini sesuai dengan hipotesis rencana bonus (the bonus plan hypothesis) dalam Positive Accounting Theory (selanjutnya, PAT) oleh Watts \& Zimmerman (1990) yang menjelaskan bagaimana mekanisme pemberian kompensasi perusahaan dapat mempengaruhi keputusan manajemen perusahaan dalam hal ini eksekutif perusahaan. Mekanisme kompensasi eksekutif adalah kontrak antara perusahaan dengan eksekutifnya yang bertujuan untuk menyelaraskan kepentingan pemilik dan eksekutif perusahaan dengan mendasarkan pemberian kompensasi atas kinerja eksekutif, seperti laba bersih dan harga saham perusahaan (Scott, 2015:403).

Conyon \& He (2014) melakukan penelitian mengenai hubungan antara kompensasi eksekutif dengan tingkat kecurangan yang terjadi di dalam perusahaan pada perusahaan publik Cina periode 2005-2010. Penelitian tersebut menemukan hasil bahwa perusahaan yang memiliki kompensasi eksekutif yang lebih rendah akan lebih cenderung untuk melakukan tindakan kecurangan. Uygur (2013) justru menemukan hasil yang berbeda pada perusahaan-perusahaan perbankan kode SIC tiga digit yaitu kompensasi eksekutif bank berpengaruh positif tehadap tindakan kecurangan. Semakin tinggi tingkat kompensasi yang diberikan kepada eksekutif perbankan justru meningkatkan terjadinya kemungkinan kecurangan.

Suatu perusahaan memerlukan adanya tata kelola yang baik untuk dapat memaksimalkan mekanisme pemberian kompensasi kepada eksekutif sehingga memberikan dampak positif bagi perusahaan yang pada akhirnya menekan terjadinya tindakan kecurangan laporan keuangan di dalam perusahaan. Salah satunya yaitu dengan hadirnya perempuan dalam jajaran direksi perusahaan. Direksi memiliki wewenang atas pengambilan keputusan untuk perusahaan yang dipimpinnya. Namun, pengambilan keputusan oleh seorang perempuan dalam jajaran eksekutif perusahaan sebagai seorang direktur berbeda dengan pengambilan keputusan oleh seorang direktur laki-laki.

Pada Gender Socialization Theory mengemukakan jika laki-laki dan perempuan memiliki nilai dan pandangan etis yang berbeda di dalam dunia kerja (Dawson, 1992). Laki-laki cenderung terlibat dalam keputusan bisnis yang lebih berisiko dibandingkan dengan perempuan yang cenderung lebih mematuhi standar etika yang ada (Harris, Karl, \& Lawrence, 2019). Oleh karena itu, ketika perempuan berada di posisi strategis sebagai pimpinan perusahaan, maka pandangan etis yang dimilikinya akan membatasi praktik kecurangan didalam perusahaan. Harris et al. (2019) juga menyatakan bahwa eksekutif yaitu CEO laki-laki terlibat dalam manipulasi yang lebih tinggi dibandingkan dengan CEO perempuan, hal tersebut dikarenakan sifat dasar perempuan yang lebih cenderung menghindari risiko dan mematuhi standar etika.

Liao et al. (2019) meneliti pengaruh gender CFO terhadap kecurangan laporan keuangan di Cina periode 2003 hingga 2015. Hasil penelitiannya menyebutkan hasil bahwa CFO perempuan memiliki pengaruh negatif terhadap kecurangan pada laporan keuangan dalam perusahaan. Peni \& Vähämaa (2010) juga melakukan penelitian tentang pengaruh eksekutif perempuan terhadap manajemen laba periode 2003 sampai 2007 pada seluruh perusahaan yang terdaftar pada S\&P 500 index. Hasilnya menunjukkan bahwa CFO perempuan memiliki hubungan dalam penurunan pendapatan akrual diskresioner yang menyiratkan bahwa CFO perempuan mengikuti strategi manajemen laba yang lebih konservatif. Puspitasari \& Januarti (2014) menemukan bahwa proporsi dari perempuan dalam direksi perusahaan dapat mengurangi kecurangan atas laporan keuangan.

\section{KAJIAN PUSTAKA DAN PENGEMBANGAN HIPOTESIS Kajian Pustaka}

\section{Positive Accounting Theory}

Positive Accounting Theory berisi tentang prediksi pilihan kebijakan akuntansi yang dilakukan oleh suatu perusahaan dan cara perusahaan tersebut memberikan respon terhadap standard akuntansi yang diajukan. Positive Accounting Theory (PAT) yang dicetuskan oleh Watts \& Zimmerman (1978) merupakan teori yang menjelaskan tentang kontrak atau dalam perusahaan. Kontrak yang ada dalam perusahaan merupakan standar yang diperlukan dalam segala aktivitas dalam perusahaan agar perusahaan terhindar dari kerugian. Kontrak tersebut muncul karena adanya perilaku oportunistik dalam kegiatan usaha. Perilaku oportunistik ini merupakan penggunaan kesempatan melalui pengetahuan manajemen (agent) atas informasi perusahaan. Manajemen akan berlaku curang dengan cara 
mengadopsi metode akuntansi tertentu pada pelaporan keuangan untuk memaksimalkan keuntungannya. Sehingga, perilaku oportunistik merupakan perilaku yang memicu terjadinya kecurangan yakni dengan menggunakan metode akuntansi untuk memaksimalkan kepentingan manajemen dan merugikan pihak principal yakni pemilik perusahaan. Tujuan dari penggunaan metode akuntansi ini adalah untuk meningkatkan atau merendahkan keuntungan dalam perusahaan.

Penelitian ini membahas mengenai kompensasi eksekutif yang artinya dalam teori posititve accounting theory, masuk dalam penjelasan management compensation hypothesis (bonus plan hypothesis). Hipotesis kompensasi manajemen (management compensation hypothesis) menyatakan manajer menerapkan suatu metode akuntansi tertentu untuk meningkatkan laba perusahaan di tahun berjalan yang akan mengarah pada meningkatnya kompensasi yang didapatkan oleh manajemen. Positive accounting theory pada penelitian ini mampu menjelaskan mengenai cara manajemen (agent) dalam melakukan kecurangan melalui tata kelola penerapan metode akuntansi dalam perusahaan. Metode akuntansi yang diterapkan dalam perusahaan dapat dilakukan atas dasar oportunistik yakni untuk menaikan kompensasi yang dapat diterima oleh manajemen. Di sisi lain, pemberian kompensasi kepada manajemen dapat membuat mereka bekerja selaras dengan tujuannya principal (pemilik perusahaan) sehingga dapat menurunkan tingkat kecurangan di perusahaan.

\section{Gender Socialization Theory}

Gender Socialization Theory menjelaskan tentang perbedaan pandangan etis dan nilai-nilai moral antara jenis kelamin akan dapat dideteksi melalui kehidupan (Dawson, 1992). Adanya perbedaan pandangan etis ini dimulai dari awal kehidupan seorang manusia, yang dipengaruhi oleh perspektif pengaruh orang tua membahas bagaimana berbagai gaya, perilaku, dan disposisi orang tua membentuk sifat dan perilaku pada anak (Carter, 2014). Perspektif pengaruh gaya mengasuh oleh orang tua akan menciptakan peran trandisional dari jenis kelamin. Gender Socialization Theory menjelaskan perbedaan gaya didik berdasarkan gender pada anak sejak lahir membuat akan memengaruhi perbedaan sifat dan perilaku etis seseorang. Laki-laki cenderung dididik untuk berani akan memengaruhi perilaku mereka untuk lebih berani dalam mengambil keputusan dan kemampuan rasionalitas. Sedangkan, perempuan yang dididik dengan penanaman nilai moral pada kasih sayang, kerapuhan membuatnya menjadi lebih peduli, taat pada perintah atau tanggung jawab, dan cenderung menghindari risiko dan hal tersebut membuat mereka lebih memiliki perilaku etis dibanding laki-laki.

Gender Socialization Theory pada penelitian ini mampu menjelaskan mengenai perilaku direksi berdasarkan gender mereka yang akan memengaruhi sikapnya dalam melakukan kecurangan akuntansi, termasuk faktor-faktor yang dapat meminimalisir kecurangan laporan keuangan berupa berupa kompensasi. Direksi perempuan dengan sifat mereka yang lebih bertanggungjawab diprediksi dapat membuat berkurangnya kecurangan laporan keuangan melalui perannya sebagai pengambil keputusan untuk menerapkan strategi yaitu pemberian kompensasi.

\section{Kecurangan Laporan Keuangan}

Kecurangan laporan keuangan merupakan bentuk tindakan yang sudah sangat dikenal dalam dunia bisnis baik nasional maupun internasional. Secara umum Association of Certified Fraud Examiners (ACFE, 2018) mendefinisikan kecurangan laporan keuangan merupakan suatu bentuk perbuatan yang meyimpang dari hukum. Perbuatan tersebut dilakukan secara sengaja bertujuan untuk memanipulasi, memberikan laporan yang menyesatkan yang dilakukan oleh pihak-pihak tertentu untuk mendapatkan keuntungan pribadi maupun kelompok, baik secara langsung maupun tidak langsung yang dapat merugikan pihak lain (Setiawati \& Baningrum, 2018). Bentuk kecurangan dalam suatu organisasi dapat dilakukan dengan berbagai macam tindakan, salah satunya adalah melakukan kecurangan laporan keuangan (Accounting Fraud). Hoi \& Robin (2010) menyatakan bahwa kecurangan laporan keuangan terjadi ketika pendapatan telah dimanipulasi secara sengaja dengan upaya untuk mencegah dan menipu investor. Ikatan Akuntan Indonesia (IAI) mendefinisikan kecurangan laporan keuangan seperti: 1) salah saji atau penghilangan sejumlah angka secara sengaja guna untuk mengelabuhi pemakai laporan keuangan. 2) salah saji timbul dikarenakan kecurangan terhadap aktiva yang berkaitan dengan pencurian aktiva entitas (Muna \& Harris, 2018).

Kecurangan laporan keuangan merupakan bentuk kejahatan penipuan laporan keuangan yang bertujuan untuk menyesatkan beberapa pihak untuk kepentingan pihak tertentu. Tindakan kecurangan laporan keuangan menimbulkan kerugian besar bagi banyak pihak serta menimbulkan skeptisisme 
terhadap akuntan dan kredibilitas laporan keuangan. Pada penelitian ini kompensasi eksekutif diharapkan dapat mempengaruhi adanya kecurangan laporan keuangan di sebuah perusahaan.

\section{Kompensasi Eksekutif}

Kompensasi eksekutif berkaitan dengan hubungan keagenan antara prinsipal dengan agen perusahaan. Jiwandono \& Rahmawati (2015) menyatakan bahwa kompensasi eksekutif merupakan hubungan antara pemilik perusahaan dan manajer perusahaan untuk menyelaraskan kepentingan bersama berdasarkan kompensasi eksekuitf dari upaya operasional manajer dalam suatu perusahaan. Jensen \& Meckling (1976) mendefinisikan kompensasi sebagai suatu imbalan yang diberikan kepada manajemen perusahaan. Jadi kompensasi eksekutif dapat menjadi mekanisme tata kelola yang dapat mempengaruhi keputusan bisnis dari eksekutif perusahaan tersebut. Pemberian kompensasi yang memadai sering dikaitkan dengan kinerja yang baik (Sun, Wei, \& Huang, 2013). Jika suatu perusahaan memberikan kompensasi yang tinggi kepada eksekutifnya diharapkan dapat menciptakan keputusankeputusan yang baik di perusahaan dan tidak merugikan pihak-pihak tertentu.

Kompensasi merupakan faktor penting yang harus diperhatikan oleh para pemilik perusahaan. Perusahaan harus kompetitif dengan memberikan beberapa jenis kompensasi kepada eksekutifnya. Beberapa bentuk kompensasi yang umum diberikan oleh perusahaan kepada karyawannya salah satunya yaitu bonus. Bonus merupakan imbalan yang diberikan perusahaan biasanya karena atas dasar pencapaian suatu target tertentu oleh karyawan. Kompensasi eksekutif berkaitan secara langsung maupun tidak langsung dengan kesejahteraan para eksekutif perusahaan. Jika eksekutif merasa mekanisme kontrak kompensasi yang diberikan oleh perusahaan telah dapat menyejahterakannya, maka dorongan untuk eksekutif perusahaan melakukan tindakan-tindakan yang merugikan pihak lain menjadi semakin berkurang. Kekuasaan, kekuatan, dan penguasaan informasi yang lebih besar dibandingkan pihak lain dimiliki oleh eksekutif perusahaan menjadikan kesejahteraan eksekutif melalui pemberian kompensasi menjadi faktor yang sangat penting dalam mempengaruhi keputusan dan strategi bisnis yang akan dihasilkan. Peneliti berharap bahwa kompensasi yang semakin tinggi akan dapat mengurangi tindakan kecurangan pada laporan keuangan pada suatu perusahaan.

\section{Keberagaman Gender Direksi}

Di Indonesia, khususnya perusahaan-perusahaan yang terdaftar di Bursa Efek Indonesia pada tahun 2007 menunjukan rata-rata proporsi perempuan yang ada di manajemen puncak adalah sebesar 11,2 persen, jumlah tersebut lebih besar daripada beberapa negara besar Eropa seperti, Jerman, Prancis, Swiss, dan Spanyol (Darmadi, 2011). Hal ini menjadikan perusahaan-perusahaan Indonesia menjadi objek menarik pada penelitian yang menyelidiki gender direksi. Indonesia juga termasuk negara yang menghargai kesetaraan terhadap gender, terlihat dari dikeluarkannya Instruksi Presiden No. 9 tahun 2000 tentang Gender dalam Pembangunan Nasional Republik Indonesia dan Peraturan Menteri Negara Pemberdayaan Perempuan dan Perlindungan Anak Republik Indonesia No. 25 tahun 2010. Intinya dari peraturan-peraturan tersebut, jika perempuan dan laki-laki memiliki kesamaan kondisi dalam memperoleh kesempatan yang sama dalam kegiatan politik, ekonomi, sosial budaya, pertahanan keamanan. Bahkan justru pada saat ini banyak yang menganggap bahwa perempuan merupakan sosok pemimpin yang lebih baik dibandingkan dengan laki-laki.

Perempuan dianggap sebagai individu yang memiliki perasaan kognitif berfokus pada keselarasandan kemampuan memfasilitasi penyebaran informasi (Earley \& Mosakowski, 2000). Perempuan lebih cenderung untuk mengambil keputusan-keputusan yang tidak berisiko tinggi bagi perusahaan dan lebih mematuhi standar-standar etika yang ada (Bosquet, De Goeij, \& Smedts, 2014).

Keberagaman gender dalam jajaran eksekutif perusahaan dimana perempuan yang berada dalam jajaran direksi dapat berperan dalam pengambilan keputusan serta strategi-strategi yang akan dilakukan perusahaan (Rahmanto \& Dara, 2020). Berdasarkan sifat alamiah yang dimiliki perempuan, maka perempuan yang berada di dewan direksi di perusahaan akan mendorong dan menghasilkan keputusan bisnis yang lebih baik. Direksi perempuan diharapkan dapat menciptakan praktik bisnis yang lebih beretika sehingga mengurangi adanya praktik-praktik kecurangan di perusahaan.

Penelitian ini menggunakan keberagaman gender direksi sebagai variabel independen, yang diharapkan kehadiran perempuan pada posisi puncak dapat mengurangi tindakan kecurangan akuntansi yakni kecurangan pada laporan keuangan. Ketika mekanisme kompensasi perusahaan telah baik dan dapat mengurangi praktik kecurangan, maka dengan hadirnya CEO perempuan dapat menjadi faktor menurunkan kecurangan pada laporan keuangan. 


\section{Hipotesis Penelitian}

\section{Pengaruh Kompensasi Eksekutif terhadap Kecurangan Laporan Keuangan}

Rencana bonus dalam Positive Accounting Theory oleh Watts \& Zimmerman (1990) menyatakan bahwa rencana kompensasi kepada eksekutif dapat mempengaruhi kebijakan eksekutif dalam menyusun angka-angka laporan keuangan. Adanya kontrak kompensasi eksekutif dapat mendorong sifat oportunistik. O'Connor et al. (2006) dan Conyon \& He (2014) memberikan hasil penelitian jika semakin besar kompensasi eksekuitf yang diberikan kepada eksekutif perusahaan dapat menekan tindakan kecurangan pada laporan keuangan. Kompensasi eksekutif dapat menjadi tata kelola perusahaan yang baik dan memberi dampak positif bagi perusahaan dan para pemangku kepentingan lainnya. Pengaruh antara kompensasi eksekutif terhadap kecurangan laporan keuangan masih menjadi perbedebatan dikalangan peneliti.Hasil temuan yang berbeda ditemukan oleh Uygur (2013) dengan hasil yakni pemberian kompensasi eksekutif yang lebih besar justru dapat mendorong tindakan kecurangan akuntansi. Chee et al. (2017) juga menemukan bukti bahwa kompensasi eksekutif yang lebih tinggi mendorong tindakan kecurangan yang lebih tinggi. Eksekutif perusahaan cenderung melakukan apa saja untuk memaksimalkan upah yang akan diperolehnya, sehingga dorongan melakukan kecurangan menjadi lebih besar. Berdasarkan perbedaan tersebut, maka hipotesis penelitian ini adalah.

$\mathrm{H}_{1}$ : Kompensasi eksekutif berpengaruh negatif terhadap kecurangan laporan keuangan.

\section{Pengaruh Keberagaman Gender Direksi terhadap Kecurangan Laporan Keuangan}

Gender Socialization Theory menyatakan bahwa bahwa laki-laki dan perempuan memiliki nilai dan pandangan etis yang berbeda di dalam dunia kerja (Dawson, 1992). Perempuan cenderung lebih mematuhi standar etika yang ada untuk keputusan bisnis karena sifatnya yang risk-averse dibanding laki-laki yang cenderung terlibat dalam keputusan bisnis yang lebih berisiko Harris et al. (2019). Francis et al. (2015), menemukan bahwa gender memang memengaruhi pengambilan keputusan. Perempuan cenderung lebih konservatis atau risk averse dalam melakukan keputusan, termasuk keputusan akuntansi. Penelitian Liao et al. (2019) tentang pengaruh gender CFO terhadap kecurangan laporan keuangan di Cina periode 2003 hingga 2015 memberikan hasil yaitu CFO perempuan memberikan pengaruh yang negatif terhadap kecurangan laporan keuangan suatu perusahaan. Wahid (2018) yang meneliti di Amerika tentang manipulasi bisnis menemukan hasil yakni jajaran eksekutif dengan gender yang lebih bervariasi memiliki keterlibatan yang rendah terhadap tindakan manipulasi keuangan. Perbedaan tersebut menjadi dasar peneliti menyusun hipotesis, maka hipotesis penelitian ini adalah:

$\mathrm{H}_{2}$ : Keberagaman gender direksi berpengaruh negatif terhadap kecurangan laporan keuangan.

\section{METODE PENELITIAN}

\section{Desain Penelitian}

Unit analisis penelitian ini adalah perusahaan manufaktur yang go public pada Bursa Efek Indonesia. Penelitian ini dilakukan selama tiga tahun, yakni tahun 2016 sampai tahun 2018. Penelitian selama tiga tahun dipilih untuk menunjukkan kondisi terupdate terkait kecurangan laporan keuangan dalam perusahaan manufaktur. Data penelitian menggunakan data sekunder. Sumber data penelitian ini diperoleh dari laporan tahunan perusahaan yang di terdapat di situs resmi Bursa Efek Indonesia (www.idx.co.id). Populasi pada penelitian ini adalah seluruh perusahaan manufaktur yang terdaftar di Bursa Efek Indonesia (BEI) pada periode tahun 2016 sampai dengan tahun 2018. Sampel pada penelitian dipilih dengan teknik purposive sampling yaitu teknik pemilihan sampel penelitian dilakukan dengan kriteria tertentu. Kriteria pemilihan sampel yang digunakan adalah sebagai berikut:

1. Perusahaan manufaktur yang terdaftar di Bursa Efek Indonesia di periode tahun 2016-2018.

2. Perusahaan menggunakan mata uang rupiah pada laporan keuangan tahunan. Hal ini dimaksudkan untuk menghindari hasil bias atau kurang tepat yang disebabkan oleh perubahan kurs mata uang.

3. Perusahaan yang IPO dan Delisting dikeluarkan dari sampel penelitian. Data tersebut dikeluarkan karena perusahaan yang terkena IPO dan Delisting tidak mengeluarkan laporan keuangan selama tiga tahun berturut-turut sehingga tidak memenuhi kriteria.

4. Perusahaan yang mengungkapkan variabel yang dibutuhkan oleh peneliti. 


\section{Definisi Operasional dan Pengukuran Variabel}

Variabel dependen dalam penelitian ini adalah kecurangan laporan keuangan. Penelitian ini mengukur kecurangan dengan cara dari Skousen \& Twedt (2009), yaitu menghitung fraud score dengan menjumlahkan kualitas akrual dan kinerja keuangan.

F-Score $=$ Accrual Quality + Financial performance

1) Accrual Quality

Richardson, Sloan, Soliman, \& Tuna (2006) dalam penelitiannya menyatakan bahwa kualitas akrual terdiri dari beberapa komponen, yaitu modal kerja (working capital), akrual operasi tidak lancar (non current operating accrual), dan akrual keuangan (financial accrual) yang disebut dengan RSST accrual.

a. RSST Accrual

$$
\begin{aligned}
& \text { RSST accrual }=\frac{(\Delta W C+\triangle N C O+\triangle F I N)}{\text { Average Total Assets }} \\
& W C=(\text { Current Assets }- \text { Cash and Short Term Investment }) \\
& \text { - (Current Liabilities - Short Term Debt) } \\
& \text { NCO }=(\text { Total Assets - Current Assets - Long Term Investment }) \\
& \text { - (Total Liabilities - Current Liabilities - Long Term Debt) }
\end{aligned}
$$

2) Financial Performance

Financial Performance $=$ change receivable + change in inventories +

change in cash sales + change in earnings.

Change in Receivable $=\frac{\Delta \text { Receivable }}{\text { Average Total Assets }}$

Keterangan:

$$
\begin{aligned}
& \Delta \text { Receivable }=\text { Receivable }_{t}-\text { Receivable }_{t-1} \\
& \text { Change in Inventories }=\frac{\Delta \text { Inventories }}{\text { Average Total Assets }}
\end{aligned}
$$

Keterangan:

$$
\begin{aligned}
& \Delta \text { Inventories }=\text { Inventories }_{t}-\text { Inventories }_{t-1} \\
& \text { Cash Sales }=\frac{\Delta \text { Sales }}{\text { Sales }_{t}}-\frac{\Delta \text { Receivable }_{\text {Recivable }}}{\text { Reterangan: }} \\
& \Delta \text { Receivable }=\text { Receivable }_{t}-\text { Receivable }_{t-1} \\
& \Delta \text { Sales }=\text { Sales }_{t}-\text { Sales }_{t-1} \\
& \text { Cash in Earnings }=\frac{{\text { Earning } s_{t}}_{\text {Average Total Assets }}}{\text { Average Total Asset } s_{t-1}}
\end{aligned}
$$

Indikator patokan nilai F-Score untuk mengukur kecurangan laporan keuangan yaitu:

Tabel 1. Indikator nilai F-Score

\begin{tabular}{ll}
\hline Nilai Rata-Rata F-Score & Kategori \\
\hline F-Score $>2,45$ & Risiko Tinggi \\
F-Score $>1,85$ & Risiko Substantial \\
F-Score $>1$ & Risiko di atas normal \\
F-Score $<1$ & Risiko Rendah \\
\hline
\end{tabular}

Variabel Independen dalam penelitian ini adalah kompensasi eksekutif dan keberagaman gender direksi.

a. Kompensasi Eksekutif

Pada penelitian ini menggunakan proksi yang dilakukan oleh Armstrong, Blouin, Jagolinzer, \& Larcker (2015), yaitu dengan menghitung total gaji, tunjangan, dan bonus yang diperoleh oleh eksekutif selama satu tahun dibagi dengan hasil penjualan perusahaan. Data untuk kompensasi dewan eksekutif terdapat dalam laporan tahunan perusahaan yang telah diaudit. 
b. Keberagaman Gender Direksi

Keberagaman gender direksi merupakan jenis kelamin orang-orang yang termasuk dalam jajaran direksi perusahaan sampel. Pengukuran gender pada penelitian ini menggunakan indeks blau yang mengacu pada penelitian (Prihatiningtias, 2012). Perhitungan Blau menjumlahkan hasil kuadrat dari nilai fraksi pria dan wanita. Semaking tinggi fraksi salah satu gender sampai pada tingkat 50 persen maka keadaan mencapai kondisi yang semakin beragam (heterogen) sementara jika salah satu fraksi pria atau wanita maka kondisi berbalik menjadi semakin tidak beragam (homogen). Untuk gender diversity, indeks berkisar antara 0 yang berarti homogeneity $(0 / 100$ proporsi gender) sampai 0,5 yang berarti tingkat maksimum.

Keterangan:

$$
\text { Blau Index }=1-\sum_{i=1}^{n} P_{i}^{2}
$$

$\mathrm{n}=$ jumlah total dewan direksi

$\mathrm{P}=$ proporsi anggota kelompok dalam kategori

\section{Persamaan Analisis Data}

Penelitian ini menguji pengaruh antara variabel independen terhadap variabel dependen. Penelitian ini menggunakan uji asumsi klasik, diantaranya uji normalitas, uji heterokesdastisitas dan uji multikolinearitas. Penelitian ini menggunakan analisis regresi berganda, karena memiliki beberapa variabel independen dan memiliki satu variabel dependen. Model Regresi Beganda pada penelitian ini adalah:

\section{Keterangan:}

$$
\mathrm{Y}=\alpha+\beta_{1} \cdot \mathrm{KOMP}+\beta_{2} \cdot \mathrm{GD}+\varepsilon
$$

$$
\begin{array}{ll}
\mathrm{Y} & =\text { Kecurangan Laporan Keuangan } \\
\alpha & =\text { Konstanta } \\
\beta_{1}-\beta_{2} & =\text { Koefisien regresi } \\
\mathrm{KOMP} & =\text { Kompensasi Eksekutif } \\
\mathrm{GD} & =\text { Keberagaman Gender Direksi } \\
\varepsilon & =\text { Error }
\end{array}
$$

\section{HASIL DAN PEMBAHASAN PENELITIAN \\ Hasil Penelitian}

Penelitian ini menggunakan tiga variabel utama, antara lain variabel kecurangan laporan keuangan sebagai variabel dependen, variabel kompensasi eksekutif dan keberagaman gender direksi menjadi variabel independen. Statistika deskriptif digunakan untuk memperoleh gambaran ataupun karakteristik data, yang meliputi nilai terendah (minimum), nilai tertinggi (maksimum), rata-rata, serta standar deviasi.

\section{Tabel 2. Hasil Uji Statistik Deskriptif}

\begin{tabular}{lllll}
\hline & Min. & Max. & Mean & Std. Dev. \\
\hline Kecurangan & $-8,16$ & 2,81 & 0,14 & 0,75 \\
Kompenasi & 0,00 & 0,32 & 0,01 & 0,02 \\
Gender & 0,00 & 0,50 & 0,18 & 0,17 \\
\hline
\end{tabular}

Jumlah data penelitian ini sebanyak 397 yang berasal dari data laporan tahunan perusahaan selama tiga tahun yaitu 2016-2018. Hasil statistika deskriptif variabel-variabel penelitian ditunjukkan pada tabel di atas. Angka gender yang terlihat dari tabel di atas menunjukkan jika terdapat variasi yang kecil antara nilai minimum dan maksimum. Angka mean 0,18 pada gender mengindikasikan angka heterogen, yang artinya CEO di perusahaan manufaktur Indonesia memiliki jumlah direksi laki-laki dan perempuan yang beragam. Hal ini terlihat dari angka pada standar deviasi lebih kecil dibandingkan angka rata-rata. Namun, pada angka kecurangan laporan keuangan dan kompensasi eksekutif terlihat memiliki standar deviasi yang lebih tinggi. Kecurangan laporan keuangan dalam penelitian ini diukur menggunakan metode $F$-score. Apabila nilai $F$-score kurang dari $1(<1)$ maka dapat dikatakan tidak terjadi kecurangan akuntansi. Pada penelitian ini menunjukkan angka mean dari kecurangan sebesar 0,14 yang bermakna bahwa perusahaan manufaktur di Indonesia pada tahun penelitian memiliki risiko yang rendah dalam melakukan kecurangan laporan keuangan. Selain itu, nilai mean pada kompensasi menunjukkan angka 0,01 yang artinya kompensasi yang diberikan kepada eksekutif perusahaan sebesar $1 \%$ dari total penjualan. 


\section{Uji Normalitas}

Hasil penelitian menunjukkan bahwa Histogram membentuk kurva lonceng serta sebaran data pada grafik Normal P-Plot menunjukkan bahwa titik yang menyebar di sekitar garis diagonal dan juga penyebaran tersebut mengikuti garis diagonal, hal ini menunjukkan bahwa angka eror terdistribusi normal.

\section{Gambar 1. Hasil Uji Normalitas}
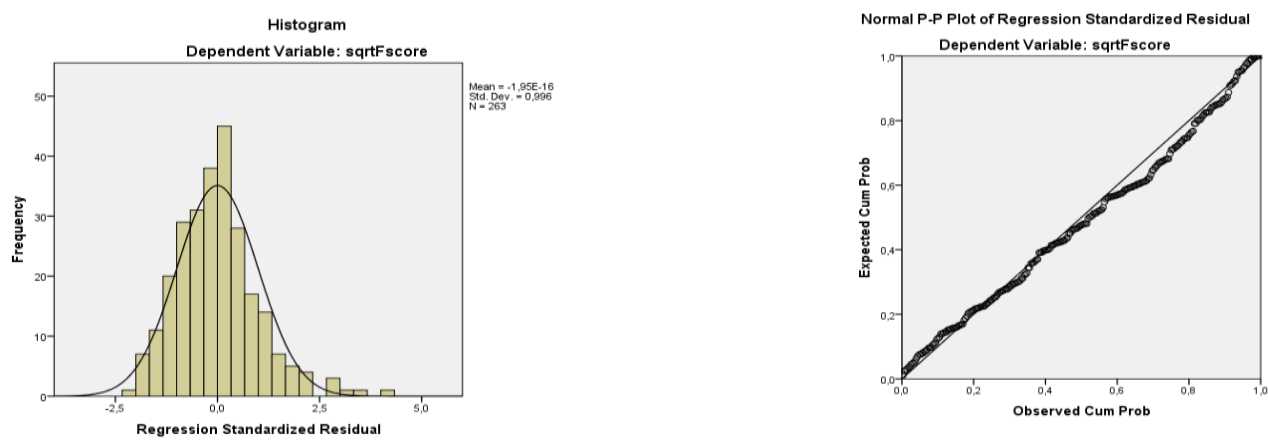

\section{Uji Heterokedastisitas}

Uji heterokedstisitas dilakukan dengan cara melihat plot antara nilai prediksi variabel dependen yaitu ZPRED dengan residualnya yaitu SRESID. Hasil uji heterokedastisitas pada Scatterplot menunjukkan bahwa titik-titik menyebar dibawah sumbu Y, dan titik-titik tersebut tidak membentuk suatu pola tertentu, sehingga dapat disimpulkan jika data penelitian ini tidak terkena gejala heterokedastisitas.

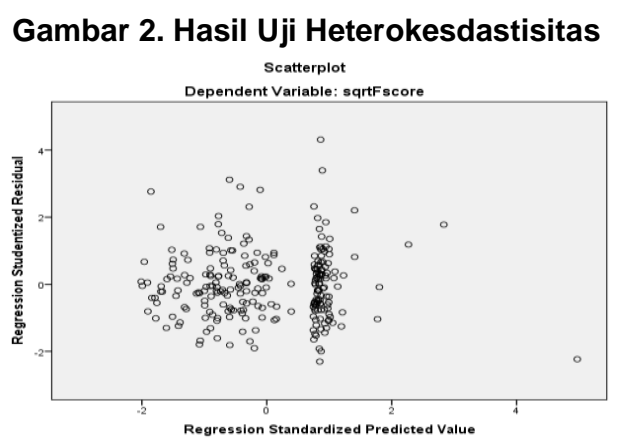

\section{Uji Multikolinieritas}

Jika hasil uji multikolinieritas menunjukkan bahwa nilai tolerance $>0,1$ dan nilai VIF $<10$ maka tidak terjadi multikolinearitas antar variabel bebas dalam persamaan regresi.

Tabel 3. Hasil Uji Multikolinieritas

\begin{tabular}{llc}
\hline Variabel & $\begin{array}{l}\text { Persamaan } \\
\text { Tolerance }\end{array}$ & VIF \\
\hline Kompensasi eksekutif & 0,986 & 1,014 \\
Keberagaman gender direksi & 0,986 & 1,014 \\
\hline
\end{tabular}

\section{Pengujian Hipotesis}

Penelitian ini memiliki dua hipotesis, hipotesis yang pertama yaitu untuk menguji apakah terdapat pengaruh dari kompensasi eksekutif terhadap kecurangan laporan keuangan. Hipotesis kedua yaitu menguji apakah terdapat pengaruh keberagaman gender terhadap kecurangan laporan keuangan.

Tabel 4. Model Regresi dan Hipotesis

\begin{tabular}{lccc}
\multicolumn{1}{c}{ Variable } & Coefficient & t-Statistic & Prob. \\
\hline Constanta & 0,626 & 27,086 & 0,000 \\
\hline KOMP & 0,590 & 0,969 & 0,833 \\
\hline GD & $-0,249$ & $-2,671$ & 0,004 \\
\hline
\end{tabular}


Hipotesis 1 yang menyatakan bahwa tidak terdapat pengaruh kompensasi terhadap kecurangan pada laporan keuangan menunjukkan pada persamaan nilai koefisien B yakni 0,590 dan probabilitas yakni 0,833 didapat dari 1-(0,334 dibagi 2), karena penelitian ini menggunakan hipotesis berarah. Koefisien B bernilai positif dan tidak signifikan $(>0,05)$. Hal tersebut membuktikan jika tidak terdapat pengaruh negatif dari kompensasi terhadap kecurangan pada laporan keuangan sehingga Hipotesis 1 ditolak.

Pada pengujian hipotesis kedua yaitu menguji apakah terdapat pengaruh dari gender terhadap kecurangan. Hipotesis 2 yang menyatakan bahwa terdapat pengaruh keberagaman gender direksi terhadap kecurangan laporan keuangan menunjukkan persamaan koefisien nilai B yaitu sebesar - 0,249 dan probabilitas sebesar 0,004, di dapat dari 0,008 dibagi 2, karna penelitian ini menggunakan hipotesis berarah. Koefisien B menunjukkan nilai negatif dan nilai siginifikan menunjukkan <0,05. Hal ini mengindikasikan bahwa terdapat pengaruh keberagaman gender direksi terhadap kecurangan atas laporan keuangan sehingga Hipotesis 2 diterima.

Pada pengujian koefisien determinasi, pada persamaan menunjukkan bahwa pengaruh kompensasi, dan gender terhadap kecurangan laporan keuangan berpengaruh sebesar 2,5\% dan 97,5\% dipengaruhi dari luar model penelitian.

\section{Pembahasan Hasil Penelitian}

Hasil pengujian pada hipotesis yang pertama penelitian ini menunjukkan jika hipotesis 1 ditolak. Hal tersebut tidak mengindikasikan pada keseluruhan perusahaan manufaktur di Indonesia tahun 2016-2018, apabila semakin tinggi kompensasi eksekutif yang diberikan kepada menajemen suatu perusahaan maka akan semakin rendah kecurangan laporan keuangan yang dilakukan dalam perusahaan. Hasil ini sesuai dengan teori stewarship yang menyatakan bahwa individu memiliki hubungan perjanjian dengan organisasinya yang mewakili komitmen moral dan mengikat kedua belah pihak untuk bekerja menuju tujuan bersama, tanpa mengambil keuntungan satu sama lain (Jefri, 2018). Hasil ini tidak sesuai dengan hipotesis rencana bonus dalam Positive Accounting Theory oleh Watts \& Zimmerman (1990) yang menyatakan bahwa rencana kompensasi kepada eksekutif dapat mempengaruhi kebijakan eksekutif dalam menyusun angka-angka pada laporan keuangan suatu perusahaan. Hasil penelitian ini berbeda dengan penelitian Hassen (2014) yang menyatakan bahwa pemberian kompensasi bonus pada dewan direksi berpengaruh pada kecurangan laporan keuangan. Hasil penelitian ini sama dengan penelitian-penelitian yang dilakukan sebelumnya. Darsono (2015) menyatakan jika kompensasi tidak mempunyai pengaruh pada kecurangan laporan keuangan. Selain itu, Noviarty, Donela, Ekonomi, \& Tanjungpura (2019) juga menyatakan jika semakin tinggi atau rendahnya kompensasi eksekutif yang diberikan kepada eksekutif perusahaan tidak berpengaruh terhadap kecurangan laporan keuangan.

Hipotesis kedua ini menyebutkan bahwa keberagaman gender direksi berpengaruh negatif terhadap kecurangan atas laporan keuangan. Hipotesis tersebut bermakna bahwa semakin banyak direksi perempuan pada suatu perusahaan, maka kecurangan laporan keuangan semakin sedikit. Hasil penelitian tersebut sama dengan penelitian-penelitian terdahulu jika gender dijadikan sebagai variabel independen. Maula \& Rakhman (2018) yang menghasilkan jika CEO Wanita berpengaruh negatif dan signifikan terhadap kecurangan laporan keuangan. Setyaningrum, Sekarsari, \& Damayanti (2019) menyatakan jika CEO wanita memberikan pengaruh negatif yang signifikan terhadap kecurangan laporan keuangan. Berbeda dengan penelitian sebelumnya, yakni penelitian Putri \& NR (2019) gender tidak bisa mendeteksi atau meminimalisirkan tingkat kecurangan pada laporan keuangan perusahaan. Laporan keuangan yang tidak dipengaruhi oleh CEO perempuan dapat terjadi dikarenakan semua keputusan yang ditetapkan harus memperoleh persetujuan seluruh pihak CEO baik laki-laki ataupun perempuan.

\section{KESIMPULAN}

Penelitian ini menghasilkan jika kecurangan laporan keuangan tidak dipengaruhi oleh kompensasi eksekutif. Hal tersebut terjadi dikarenakan adanya kemungkinan bahwa pihak-pihak yang ingin memperoleh hasil yang lebih dibandingkan jumlah kompensasi yang dimilikinya. Hasil lain penelitian ini membuktikan bahwa kecurangan laporan keuangan dapat diminimalisir atau diturunkan dengan adanya keberagaman gender direksi. Semakin banyak jumlah direksi wanita pada suatu perusahaan, maka semakin kecil risiko kecurangan laporan keuangan dalam perusahaan. 
Keterbatasan penelitian ini adalah kurangnya kelengkapan informasi seperti tidak lengkapnya data kompensasi yang dibutuhkan dalam penelitian. Selanjutnya, model penelitian ini menunjukkan jika variabel independen penelitian yang digunakan hanya dapat menjelaskan sebesar 2,5\%, sedangkan sebesar 97,5\% dijelaskan oleh faktor lainnya yang tidak diteliti oleh peneliti dalam penelitian ini. Berdasarkan keterbatasan tersebut maka saran peneliti untuk kesempurnaan peneliti selanjutnya adalah memperluas cakupan sumber data sehingga jumlah observasi (sampel) penelitian dengan konteks yang sama dapat menyeluruh untuk semua perusahan. Selain itu, peneliti selanjutnya dapat melakukan perubahan variabel penelitian atau menambahkan variabel lain terkait dengan kecurangan laporan keuangan.

\section{REFERENSI}

ACFE. (2018). Report to the Nations, 2018 Global Study on Occupational Fraud and Abuse AsiaPacific Edition. Retrieved July 30, 2019, from ACFE website: https://www.acfe.com

Armstrong, C. S., Blouin, J. L., Jagolinzer, A. D., \& Larcker, D. F. (2015). Corporate governance, incentives, and tax avoidance. Journal of Accounting and Economics, 60(1), 1-17. https://doi.org/10.1016/j.jacceco.2015.02.003

Bosquet, K., De Goeij, P., \& Smedts, K. (2014). Gender heterogeneity in the sell-side analyst recommendation issuing process. Finance Research Letters, 11(2), 104-111. https://doi. org/10.1016/j.frl.2013.11.004

Carter, M. J. (2014). Gender socialization and identity theory. Social Sciences, 3(2), 242-263. https://doi.org/10.3390/socsci3020242

Chee, S., Choi, W., \& Shin, J. E. (2017). The non-linear relationship between CEO compensation incentives and corporate tax avoidance. Journal of Applied Business Research, 33(3), 439-450. https://doi.org/10.19030/jabr.v33i3.9935

Conyon, M. J., \& He, L. (2014). Executive Compensation and Corporate Fraud in China. Journal of Business Ethics, 134(4), 669-691. https://doi.org/10.1007/s10551-014-2390-6

Darmadi, S. (2011). Board diversity and firm performance: The indonesian evidence. Corporate Ownership and Control, 9(1 F), 524-539. https://doi.org/10.22495/cocv8i2c4p4

Darsono, S. N. (2015). Pengaruh Kompensasi, Kepemilikan Manajerial, Diversifikasi Perusahaan Dan Ukuran Kap Terhadap Manajemen Laba. Diponegoro Journal of Accounting, 4(3), 1-13.

Dawson, L. M. (1992). Will feminization change the ethics of the sales profession? Journal of Personal Selling and Sales Management, 12(1), 21-32. https://doi.org/10.1080/08853134.1992.10753895

Dewi, G., \& Sari, M. (2015). Pengaruh Insentif Eksekutif, Corporate Risk dan Corporate Governance Pada Tax Avoidance. E-Jurnal Akuntansi Universitas Udayana, 13(1), 50-67.

Earley, P. C., \& Mosakowski, E. (2000). Creating hybrid team cultures: An empirical test of transnational team functioning. Academy of Management Journal, 43(1), 26-49. https:// doi.org/10.2307/1556384

Finnerty, J. D., Hegde, S., \& Malone, C. B. (2016). Fraud and Firm Performance: Keeping the Good Times (Apparently) Rolling. Managerial Finance, 42(2), 151-172.

Francis, B., Hasan, I., Park, J. C., \& Wu, Q. (2015). Gender Differences in Financial Reporting Decision Making: Evidence from Accounting Conservatism. Contemporary Accounting Research, 32(3), 1285-1318. https://doi.org/10.1111/1911-3846.12098

Hanafi, U., \& Harto, P. (2014). Analisis Pengaruh Kompensasi Eksekutif, Kepemilikan Saham Eksekutif Dan Preferensi Risiko Eksekutif Terhadap Penghindaran Pajak Perusahaan. Diponegoro Journal of Accounting, 3(2), 1-11.

Harris, O., Karl, J. B., \& Lawrence, E. (2019). CEO compensation and earnings management: Does gender really matters? Journal of Business Research, 98, 1-14. https://doi.org/10.1016/j. jbusres.2019.01.013

Hassen, R. Ben. (2014). Executive Compensation and Earning Management. International Journal of Accounting and Financial Reporting, 4(1), 84-105. https://doi.org/10.5296/ijafr.v4i1.5453

Hoi, C. K., \& Robin, A. (2010). Labor market consequences of accounting fraud. Corporate Governance, 10(3), 321-333. https://doi.org/10.1108/14720701011051947

Hoi, C. K., \& Robin, A. (2010). Labor market consequences of accounting fraud. Corporate Governance, 10(3), 321-333. https://doi.org/10.1108/14720701011051947 
Jefri, Riny. (2018). Teori Stewardship dan Good Governance. Jurnal Riset Edisi XXVI. Unibos Makassar.

Jensen, M. C., \& Meckling, W. H. (1976). Theory of The Firm Manajerial Behaviour, Ageny Cost and Ownership structure. Journal of Financial Economics, 3, 305-360.

Jiwandono, L. Y., \& Rahmawati. (2015). Total Kompensasi Eksekutif dan Manajemen Laba Riil (Studi Empiris pada Perusahaan Manufaktur yang terdaftar di BEI Tahun 2010-2013). Jurnal Akuntansi Dan Bisnis, 15(1), 23-31.

Liao, J., Smith, D., \& Liu, X. (2019). Female CFOs and accounting fraud: Evidence from China. Pacific Basin Finance Journal, 53(January), 449-463. https://doi.org/10.1016/j.pacfin.2019.01.003

Mammen, R. S., \& Edakalathur, V. V. (2019). Forensic Accounting: Impact of Fraud on Stock Price. International Journal of Business and Management Invention (IJBMI), 8(1), 89-95.

Maula, K. A., \& Rakhman, A. (2018). Pengaruh Board Diversity (Ceo Wanita, Cfo Wanita, Proporsi Dewan Komisaris Wanita, Proporsi Komite Audit Wanita) Terhadap Pelanggaran Aturan Laporan Keuangan. Accounthink: Journal of Accounting and Finance, 3(01), 431-445. Retrieved from http://dx.doi.org/10.35706/acc.v3i01.1208

Muna, B. N., \& Harris, L. (2018). Pengaruh Pengendalian Internal Dan Asimetri Akuntansi (Penelitian Persepsi Pengelola Keuangan pada Perguruan Tinggi Negeri). Jurnal Akuntansi, Ekonomi Dan Manajemen Bisnis, 6(1), 35-44.

Noviarty, H., Donela, V., Ekonomi, F., \& Tanjungpura, U. (2019). Pengaruh Kompensasi Eksekutif Terhadap Manajemen Laba Dengan Profitabilitas Sebagai Variabel Moderating (Studi Empiris Pada Perusahaan Perbankan Yang Terdaftar Di Bursa Efek Indonesia). Jurnal Audit Dan Akuntansi Fakultas Ekonomi Dan Bisnis Universitas Tanjungpura, 8(1), 43-72.

O'Connor, J. J. P., Priem, R. I., \& Coombs, J. E. (2006). Do CEO Stock Options Prevent or Promote Fraudulent Financial Reporting? Academy of Management Journal, 49(3), 483-500. https://doi. org/10.5465/AMJ.2006.21794666

Peni, E., \& Vähämaa, S. (2010). Female executives and earnings management. Managerial Finance, 36(7), 629-645. https://doi.org/10.1108/03074351011050343

Prihatiningtias, Y. W. (2012). Gender diversity in the boardroom and firm performance : evidence from indonesian publicly- listed financial firms a thesis submitted to the university of canberra for the degree of doctor of business administration. Retrieved from http://www.canberra.edu.au/re searchrepository/file/a669fbb3-5a71-e95b-ac65-7fc71b83691c/1/full_text.pdf

Puspitasari, D., \& Januarti, I. (2014). Pengaruh Keberadaan Wanita dalam Keanggotaan Keuangan Perusahaan (Studi Empiris pada Perusahaan Non-financial yang Terdaftar di Bursa Efek Indonesia Tahun 2007-2012). Diponegoro Journal of Accounting, 3(3), 1-15.

Putri, N. G., \& NR, E. (2019). Pengaruh Keahlian Akuntansi Komite Audit dan Dewan Komisaris Wanita Terhadap Manajemen Laba. Jurnal Eksplorasi Akuntansi, 1(3), 1051-1067.

Rahmanto, B. T., \& Dara, S. R., (2020). Diversitas Gender Dan Kinerja Keuangan Sektor Farmasi di Indonesia. Jurnal Proaksi, 7(2), 183-193. https://doi.org/10.32534/jpk.v7i2.1290

Richardson, S. A., Sloan, R. G., Soliman, M. T., \& Tuna, I. (2006). The implications of accounting distortions and growth for accruals and profitability. Accounting Review, 81(3), 713-743. https://doi.org/10.2308/accr.2006.81.3.713

Scott, W. R. (2015). Financial Accounting Theory (Seventh). United State of America: Pearson.

Setiawati, E., \& Baningrum, R. M. (2018). Deteksi Fraudulent Financial Reporting Menggunakan Analisis Fraud Pentagon : Studi Kasus Pada Perusahaan Manufaktur Yang Listed Di Bei Tahun 2014-2016. Riset Akuntansi Dan Keuangan Indonesia, 3(2), 91-106. https://doi.org/10.23917/reaksi.v3i2.6645

Setyaningrum, G. C., Sekarsari, P. S. S., \& Damayanti, T. W. (2019). Pengaruh Eksekutif Wanita (Female Executive) Terhadap Manajemen Laba. Jurnal Ekonomi Dan Perbankan, 4(1), 98-110. Retrieved from http://e-journal.stie-aub.ac.id/index.php/probank

Skousen, C. J., \& Twedt, B. J. (2009). Fraud score analysis in emerging markets. Cross Cultural Management: An International Journal, 16(3), 301-316. https://doi.org/10.1108/135276009 10977373

Sun, F., Wei, X., \& Huang, X. (2013). CEO compensation and firm performance: Evidence from the US property and liability insurance industry. Review of Accounting and Finance, 12(3), 252-267. https://doi.org/10.1108/RAF-Jan-2012-0006 
Syahrul, Y. (2003). Bapepam: Kasus Kimia Farma Merupakan Tindak Pidana. Retrieved July 29, 2019, from Bisnis Tempo website: https://bisnis.tempo.com

Uygur, O. (2013). Earnings management and executive Compensation: Evidence from banking industry. Banking and Finance Review, 5(2), 33-54.

Wahid, A. S. (2018). The Effects and the Mechanisms of Board Gender Diversity: Evidence from Financial Manipulation. Journal of Business Ethics, 1-21. https://doi.org/10.1007/s10551-018$3785-6$

Watts, R. L., \& Zimmerman, J. L. (1978). Towards a Positive Theory of the Determination of Accounting Standards Towards a Positive Theory of the Determination of Accounting. The Accounting Review, 53(I), 112-134. Retrieved from http://www.jstor.org/stable /245729\% 0Ahttp ://about.jstor.org/terms

Watts, R. L., \& Zimmerman, J. L. (1990). Accounting Year Theory: Ten Perspective. The Accounting Review, 65(1), 131-156. 